DALIBOR GOTTWALD, Ph.D. ${ }^{1}$

(Corresponding author)

E-mail: dalibor.gottwald@upce.cz

EVA ZÁKOROVÁ, Ph.D. ${ }^{1}$

E-mail: eva.zakorova@upce.cz

LIBOR ŠVADLENKA, Ph.D. ${ }^{1}$

E-mail: libor.svadlenka@upce.cz

HANA PAVLISOVÁ2

E-mail: h.pavlisova@post.cz

${ }^{1}$ University of Pardubice

Faculty of Transport Engineering

Studentská 95, 53210 Pardubice, Czech Republic

2 Palacký University Olomouc, Faculty of Arts

Křǐžkovského 10, 77200 Olomouc, Czech Republic
Transport Management

Review

Submitted: 18 Sep. 2017

Accepted: 10 July 2018

\title{
APPROACH TO HUMAN CAPITAL IN NATIONAL POSTAL PROVIDERS: A CROSS-COUNTRY ANALYSIS IN EUROPE
}

\begin{abstract}
The article investigates human capital in national postal providers (NPPS), which is an area that has yet to be underpinned by research. There is a number of works dealing with human capital, but only few address human capital in the postal service sector. The main aim of the article is to define differences in approach to human capital management in selected NPPs. Differences are expressed via the overall Human Capital Index $(\mathrm{HCl})$. Due to the fact that so far there has been no complex research analyzing activities related to human capital in NPPs, it was necessary to carry out a content analysis of annual reports of selected NPPs. Results of the analysis served as a basis for expression of overall $\mathrm{HCl}$. This study brings new insights into the topic and contributes to the sustainable development of the field.
\end{abstract}

\section{KEY WORDS}

human capital; national postal providers; postal service;

\section{INTRODUCTION}

Human capital is currently a much debated topic. It is closely related to a change in the philosophy of company management. Human capital as a part of intellectual capital has gradually established itself as an area whose effective management is essential for increasing a company's value. At the moment, there are virtually no areas of company activity that are not affected by the human factor. For this reason there has been an elevated interest in human capital both on the part of managements of companies and the scientific community. This interest has been driven by efforts to identify, analyze and effectively manage all processes that directly affect individuals (employees) or groups of individuals (groups of employees).
Results of scientific studies dealing with human capital provide company managements with vital information on the interrelations of various social constructs. Social construct is defined as an area which is constructed into a process of social interaction and communication among individuals or groups of individuals. Social interaction is defined as a process in which an individual (or a group of individuals) exerts influence upon another individual (or a group of individuals) in a system [1], whose interaction encourages the formation of human capital. Because of the number of works dealing with this topic, definitions of human capital slightly vary from author to author. It is thus necessary to understand human capital from a particular author's point of view. The works on human capital can be divided into two large groups, focusing either on the micro-economic or the macro-economic level. The former investigate interactions of social constructs that form human capital within a company, while the latter look into interactions that form human capital outside of a company on the societal level.

Transport and telecommunications is one of the basic sectors of national economy in all countries. This sector also includes postal service, which is regulated by laws of each country. Among other postal service providers, national postal providers (NPPs) play an important role. These entities must by virtue of their function guarantee provision of universal postal service in the general/public interest. This universal postal service is practically exclusively provided by NPPs. Universal postal service represents a minimal set of services that must be provided continually nationwide under the same conditions for all users, for an affordable price and to a specified quality [2]. The Universal Postal Union (UPU) is the supreme postal authority with 192 members. The UPU coordinates the 
operation of the postal market and discusses current trends related to its development. Human capital is one of the areas which are currently being discussed in relation to development of postal market.

This article sets out to show the differences in approach to human capital management in selected European NPPs.

In order to do that, it was necessary to:

- Define main areas of approach to human capital in selected NPPs, i.e., identify concrete activities which are organized in relation to human capital.

- Categorize the identified activities into components according to areas they focus on.

- Express the overall Human Capital Index ( $\mathrm{HCl})$.

- Discuss any discovered links and relations that are relevant for the used methodology and consider various perspectives that must be present in the research of human capital.

The article deals with a topical issue in a completely new context, in which human capital has not been researched so far. The results of the article provide a solid ground for further research.

Section 2 of the paper deals with the background and literature related to this topic. Section 3 defines the methodology used for the calculation of the overall $\mathrm{HCl}$, while the fourth section presents the results of its application to a sample of NPPs. In Section 5 we discuss the results and broader context to which the results are applicable. The last section sums up the conclusions.

\section{BACKGROUND AND RELATED LITERATURE}

Human capital is an area of economic sciences and forms a part of a relatively new economic sub-discipline called intellectual capital. Intellectual capital came into the forefront of interest after the endogenous growth theory was proposed in the 1980s. It holds that intellectual capital is an endogenous factor, meaning that it does not occur randomly, but has to be produced with the use of resources. The importance of human capital in ensuring sustainable growth is mentioned by Coleman [3], who claims that, in order to ensure sustainable growth, it is necessary to respect newly established social constructs, which are essential in the process of establishing trust and loyalty among members of a particular group. Intellectual capital is viewed as an area whose formation is affected by many social constructs. Edvinsson and Malone [4] examined the intangible components which influence the value of a company and classified intellectual capital as follows:

- Human capital - comprises people's knowledge, skills, experience, and abilities, such as the ability to innovate, creativity, know-how, previous experience, flexibility, the ability to work in a team, work motivation and satisfaction, the ability to learn, loyalty, education.

- Structural capital - consists of organizational capital and customer capital. It is closely related to internal processes, knowledge, and abilities.

- Customer capital - covers long-term relationships of a company with its most prominent customers, including information about those customers and their specific needs.

- Organizational capital - comprises traditional intellectual assets (such as patents), databases, and IT. Generally, even various cultural aspects can be included in this category, such as the culture of knowledge sharing and collaboration. Organizational capital is made up of innovation capital and process capital.

- Process capital - expresses a company's ability to improve and document internal processes.

- Innovation capital - expresses a company's ability to react to the future market developments. It is comprised of intellectual property and intangible assets.

- Intangible assets - all assets of intangible nature. For each company, the most valuable assets are those that are original and difficult to imitate.

- Intellectual property - proprietary rights of companies, related to intangible assets.

Donate et al., Marzo and Scarpina, Rossi et al., and Yaseen et al. [5-8] examine the impact components of intangible assets have on the increase of a company's value. Human capital is currently viewed as a tool that can significantly increase the value of a company. For this reason, its further investigation is highly relevant [9-11].

As mentioned above, studies dealing with this topic can be divided into two large groups according to author's definition of human capital. The first group investigates human capital from the micro-economic perspective. These works usually bring analyses of selected activities related to employee development in a particular company - an employee is seen as a basic entity which determines the value of human capital. In addition, they analyze the causal relationships among indicators of employee satisfaction levels and other internal performance-related indicators [12-15]. The second group examines human capital from the macro-economic perspective. These authors usually understand human capital as an area whose effective management leads to increase in economic performance and overall economic stability of a country [16-18].

The macro-economic perspective also deals with the individual. As Kirdina [19] notes, the discussion about macro and microeconomic approaches to the role of an individual has been one of the main topics in sociology in the last few years. In his view, an 
individual is influenced by their surrounding environment, which is reflected in the way they execute work tasks. Their individual performance is then reflected in the company's overall performance. This way, the society as a whole influences the company.

In order to provide a comprehensive overview of works dealing with human capital, it is necessary to mention works that combine both micro and macroeconomic approaches. To name just a few, Polachek et al. [20] use a tractable nonlinear earnings function to derive ability measures and show their link to cognitive ability, personality traits, and family background. Wright and Boswell [21] oppose the 1980s division of human resource management (HRM) into two independent areas (strategic and functional) and propose a typology of HRM research based on two dimensions (level of analysis - individual/group or organization and number of practices - single or multiple) which they apply to review recent research in this area. They claim that although significant progress has been made in each area of HRM, potential for even greater gains lies in looking across each area. Both areas can significantly contribute to each other and result in a greater impact on HRM than each one can contribute independently, and thus a more integrative view of HRM is needed. Authors use the term "human resource management", rather than human capital management. This is because the term human capital management as we understand it now started to be widely used only after the publication of works of Edvinsson and Malone (1990). Human capital management is currently discussed in relation to coordination of activities promoting employee development (not only activities which are carried out by human resources departments such as employee motivation, rewarding employees, etc., but also other activities, such as improvement of working conditions, better communication, diversity management, etc.). Human capital management is thus an add-on to the concept of human resources management. Various activities are therefore coordinated in accordance with the current development trends in a given sector and respect the employee as an individual whose general attitudes are reflections of the society in which his or her individuality is formed [5]. Ployhart and Moliterno [22] propose a multilevel model to analyze the emergence of human capital as a firm resource that connects micro, intermediate, and macro levels. The model comprises three parts: cognitive and non-cog nitive characteristics of an individual, how they are combined and amplified in the interaction with others, and finally how human capital emerges from these processes.

The number of works on human capital makes it evident that it is a modern area of concern, reflecting today's globalized world. For this reason it is necessary to respect all possible overlaps in the definitions of human capital, as various authors or works define it differently [23-26]. It must be stressed that currently there are no scientific studies dedicated to approach to human capital in postal services. It was therefore necessary to carry out a pioneer analysis of the state of the art (see Section 2). The research was done by means of content analysis of annual reports. This method is not a new one; on the contrary, it has been used in many works published in scientific journals [27-35].

\section{METHODOLOGY}

Of the three possible approaches to human capital investigation (microeconomic, macroeconomic, combination of both), this study represents the third type, as it demonstrates the differences in approach to human capital management in selected NPPs. In order to do this, approach to human capital in each NPP must be investigated in the first place (microeconomic perspective). Then, following the below described methodology, the issue can be investigated in a more complex way within the group of sample NPPs (macroeconomic perspective). The section is divided into two subsections. The first one describes in detail the steps taken in analyzing the current state of approach to human capital in NPPs by means of a content analysis of annual reports. The second subsection describes the process of calculation of overall $\mathrm{HCl}$.

\subsection{Content analysis of annual reports}

The selection of NPPs was governed by the deadline for the publication of their 2015 annual reports, which was set to 20 September 2016. Some NPPs had not published their reports by this date and therefore were not included. In the end, thirteen NPPs have been subjected to the analysis, namely: Poste Italiane (Italy), La Poste (France), Bpost (Belgium), Deutsche Post (Germany), PostNL (Netherlands), AN Post (Ireland), Correos y Telégrafos (Spain), Posti Ltd (Finland), Österreichische Post AG (Austria), Posten Sweden Post (Sweden), Česká pošta (Czech Republic), Lietuvos Pastas (Lithuania), and Magyar Posta (Hungary). The final sample comprises thirteen NPPs that are more or less evenly distributed around Europe and thus represent all its geographical parts. For this reason, it was unnecessary to broaden the sample with 2014 annual reports of those NPPs that had not completed their 2015 annual report by the deadline.

The process of content analysis of annual reports has a number of subprocesses. At the beginning it was necessary to appoint people who would carry out the content analysis. It was done by three researchers, who worked individually to ensure maximum objectivity of the analysis. It was necessary to appoint committed people who would fully identify with the aim of the article and were educated accordingly. 
The next step was the identification of activities that were to be sought for by the researchers in the annual reports. These are the activities that were organized by the NPP for the purpose of employee development: not only activities designed by human resources management departments, but also other activities, such as improvement of working conditions, better communication, diversity management, etc. Authors draw on the general paradigm that an employee is a basic entity which determines the level of human capital. For this reason it was necessary to search for all activities that are organized for the purpose of employee development across all areas. Therefore it was not possible to focus only on chapters dealing with description of activities of HR departments, but it was necessary to analyze the whole text of annual reports, 2,582 pages in total.

Each researcher produced a list of identified activities, which were compared in the next step. In case of any divergence, such as when one researcher did not identify an activity which was identified by the other two, it was necessary to repeat the whole process. This procedure was repeated until full compliance was achieved among the three researchers. The output of the content analysis is the list of activities of approach to human capital in European NPPs (Table 1).

The list is divided into individual components according to the field (such as Health and safety, Working conditions, Benefits and other forms of support, Diversity management, etc.).

This list will be used for the expression of the overall Human Capital Index $(\mathrm{HCl})$, which will serve as a basis for the demonstration of differences in approach to human capital management in selected NPPs.

\subsection{Calculation of overall $\mathrm{HCl}$}

Firstly, three independent evaluators (the same evaluators who participated in the content analysis of NPPs' annual reports) were appointed and the methodology for evaluation was set. It had to be determined which activities are organized at which NPP, because the number varies, and some NPPs organize more activities than others. This led to the creation of an overview of activities that are organized at each NPP. It was also important to reflect the differences in the form of implementation as some NPPs implement activities in a rather sophisticated way (such as in the form of a long-term project), while others implement it only marginally (the project does not yet exist, but is in the making).

In the process of evaluation, activities were assigned a value according to the following key: 0 - activity is not implemented; 1 - activity is not yet implemented, however, a draft of its implementation process has already been prepared or is in the making; 2 - activity is already implemented (project, process, evaluation, etc.).

Each activity from Table 1 can be assigned the value 0,1 , or 2 . Even if there are more projects/processes for one type of activity, the maximum value is still 2. The value of each component is calculated by Equation 1 (see below). The researchers evaluated activities independently and then discussed and compared their results. In case of any divergence it was necessary to carry out the whole process again.

The next step was a comprehensive evaluation of approach to human capital. This indicator serves as a basis for the determination of differences in approach to human capital.

To determine the overall $\mathrm{HCl}$, it is necessary to observe:

- the number of identified activities and their categorization (i.e., the distribution of individual activities into components),

- evaluations of individual activities in individual NPPs.

Each component consists of a number of activities. To calculate the overall $\mathrm{HCl}$, it was necessary to calculate the value of each component using the following formula:

$$
X_{j}=\frac{1}{n} \sum_{j=1}^{n} x_{n j}
$$

where:

$X_{j}$-the total value of each component $(\mathrm{A}-\mathrm{H})$

$j$-the sequence number of a component $(\mathrm{A}-\mathrm{H})$

$n$-the number of activities in a component

$x_{n j}$-the value of an activity $n j \in\{0,1,2\}$

The overall $\mathrm{HCl}$ can only be expressed when each main component has been calculated. In this case, the overall $\mathrm{HCl}$ consists of eight principal components: Safety at work, employee health protection, working conditions (A); Benefits and other forms of support (B); Education, training and skills (C); Communication (D); Organizational structure, infrastructure (E); Diversity management $(F)$; Demographic structure $(G)$; and Information gathering $(\mathrm{H})$.

The overall $\mathrm{HCl}$ will serve for the formulation of differences in approach to human capital. For this reason, it was convenient to choose such a method that would allow for a clear expression of the position of each component's total value at one NPP to the position of the same component's value at the remaining NPPs. One such method is the z-score method [36]. Mathematical formulas are used in this context to find the population mean, standard deviation, and the z-score of a member of a population. The normalized score is the signed number, therefore, the higher and lower values indicate that the z-score is above or below the mean, respectively. 
Gottwald D, Zákorová E, Švadlenka L, Pavlisová H. Approach to Human Capital in National Postal Providers: A Cross-country Analysis...

Table 1 - List of activities of approach to human capital in European NPPs

\begin{tabular}{|c|c|}
\hline \multicolumn{2}{|c|}{ A: Safety at work, employee health protection, working conditions } \\
\hline A1 & Programs (seminars, lectures) of prevention of accidents at work and occupational diseases \\
\hline A2 & Creating conditions for increasing safety at work \\
\hline A3 & Stress management programs (seminars, lectures) \\
\hline A4 & The possibility to consult a psychologist \\
\hline A5 & Modern technology programs (pocket computers, smartphones) \\
\hline \multicolumn{2}{|c|}{ B: Benefits and other forms of support } \\
\hline B1 & Supporting art associations and associations of employees \\
\hline B2 & Supporting sports activities \\
\hline B3 & Supporting employees in volunteering \\
\hline B4 & Declared employee benefits \\
\hline B5 & Other (benefits beyond list of declared benefits) \\
\hline \multicolumn{2}{|c|}{ C: Education, training and skills } \\
\hline $\mathrm{C} 1$ & Educational institutions for employees (company university, in-house department) \\
\hline $\mathrm{C} 2$ & Cooperation with educational institutions (high schools, universities) in training courses \\
\hline $\mathrm{C} 3$ & Programs (seminars, lectures) to increase employees' qualifications \\
\hline C4 & Programs of skills development (active skills training) \\
\hline $\mathrm{C} 5$ & Cooperation with other persons (trainers, mentors, consultants) in skills training \\
\hline \multicolumn{2}{|c|}{ D: Communication } \\
\hline D1 & Use of new communication tools \\
\hline D2 & Intranet, company newspaper \\
\hline D3 & Programs to improve communication among departments \\
\hline D4 & Ethics (code of conduct), professional communication \\
\hline \multicolumn{2}{|c|}{ E: Organizational structure, infrastructure } \\
\hline E1 & Procedural approach dealing with employees' activities (ISO 9001, ISO 14001) \\
\hline E2 & Targeted delegation of employee authorizations \\
\hline E3 & Programs of career development support \\
\hline E4 & Programs of mobility \\
\hline E5 & Working hours management \\
\hline \multicolumn{2}{|c|}{ F: Diversity management } \\
\hline F1 & Creating conditions for supporting employees from other countries \\
\hline F2 & Programs of integration of employees with limited capacity to work \\
\hline F3 & Programs of supporting employees on parental leave \\
\hline F4 & Raising awareness of diversity management \\
\hline F5 & Support of employee charity organizations \\
\hline \multicolumn{2}{|c|}{ G: Demographic structure } \\
\hline G1 & Programs of gender equality \\
\hline G2 & Analysis of available information on gender differences (salary, department structure) \\
\hline G3 & Programs of junior employee support \\
\hline G4 & Programs of senior employee support \\
\hline \multicolumn{2}{|c|}{ H: Information gathering } \\
\hline H1 & Feedback from employees - satisfaction with activities in component $A$ \\
\hline $\mathrm{H} 2$ & Feedback from employees - satisfaction with activities in component D \\
\hline H3 & Feedback from employees - satisfaction with activities in component $\mathrm{E}$ \\
\hline $\mathrm{H} 4$ & Gathering information on employee satisfaction (questionnaires) \\
\hline H5 & Regular reporting (related to strategy) \\
\hline $\mathrm{H} 6$ & Gathering information on employee satisfaction (interviews) \\
\hline $\mathrm{H} 7$ & Assessing employees to create staff reserves \\
\hline
\end{tabular}


The formula to find z-score:

$z=\frac{x-\mu}{\sigma}$

where:

$z$-the z-score

$x$-a raw score to be standardized

$\mu$-the sample mean of the population

$\sigma$-the sample standard deviation of the entire population

Z-score was expressed for total value of each component, and then the resulting overall $\mathrm{HCl}$ was calculated from the eight partial scores using the following formula:

$H C I=\frac{1}{m} \sum_{j=1}^{m} Z_{m j}$

where:

$H C I$-the overall Human Capital Index

$m$-the number of components

$j \quad$-the sequence number of a component $(\mathrm{A}-\mathrm{H})$

$Z_{m j}$-the z-score of the number of a component $(\mathrm{A}-\mathrm{H})$

\section{RESULTS}

This section presents the results of the analysis of thirteen annual reports. The results in Table 2 show z-scores within groups of each eight components (columns $\mathrm{A}-\mathrm{H}$ ). These scores were used to calculate the overall $\mathrm{HCl}$.

La Poste scored the highest (1.353), followed by Correos y Telégrafos (0.735) and PostNL (0.695). On the other hand, Magyar Posta and Lietuvos Pastas scored the lowest (-0.909 and -0.755 , respectively).
The highest score for each component is highlighted. In component A (Safety at work, employee health protection, working conditions), Correos y Telégrafos scored the highest with 2.697; in component B (Benefits and other forms of support) it was Correos y Telégrafos, bpost, and La Poste with the same score of 1.461; in C (Education, training and skills) PostNL ranked first with the score of 1.598; in D (Communication) it was Correos y Telégrafos again (2.040); in E (Organizational structure, infrastructure) it was La Poste (2.313); in F (Diversity management) Poste Italiane scored the highest with 2.259; in G (Demographic structure) it was La Poste (2.313); and, finally, in H (Information gathering) PostNL and Posten Sweden Post scored the highest with 1.317.

Figure 1 shows the number of positive and negative z-scores in the group of analyzed NPPs. La Poste scored the highest on the overall $\mathrm{HCl}$ and achieved a positive score in all components. On the other hand, bpost, which ranked fourth on the overall $\mathrm{HCl}$, shows only one negative z-score (in G - Demographic structure), while Correos y Telégrafos, which ranked second, shows a negative z-score in three components (C - Education, training and skills; G - Demographic structure; $\mathrm{H}$ - Information gathering). This is given by the fact that bpost has in many components a positive score which is very close to zero, i.e., the average z-score. Magyar Posta and Lietuvos Pastas achieved the highest number of negative scores.

It must be stressed that individual NPPs are in no way similar to each other. Their dissimilarity can be exemplified in a number of ways. This argument is further developed in the discussion.

Table 2 - Z-score values of each component and the overall $\mathrm{HCl}$

\begin{tabular}{|l|c|c|c|c|c|c|c|c|c|c||}
\hline & $\mathrm{A}$ & $\mathrm{B}$ & $\mathrm{C}$ & $\mathrm{D}$ & $\mathrm{E}$ & $\mathrm{F}$ & $\mathrm{G}$ & $\mathrm{H}$ & $\mathrm{HCl}$ & $\mathrm{Rank}$ \\
\hline \begin{tabular}{l}
\hline Österreichische \\
Post AG
\end{tabular} & -0.809 & 0.151 & -0.098 & 0.000 & -0.531 & -0.371 & -0.125 & 0.000 & -0.223 & 9 \\
\hline $\begin{array}{l}\text { Correos y } \\
\text { Telégrafos }\end{array}$ & 2.697 & 1.461 & -0.098 & 2.040 & 0.688 & 0.944 & -0.531 & -1.317 & 0.735 & 2 \\
\hline $\begin{array}{l}\text { Posten Sweden } \\
\text { Post }\end{array}$ & -1.247 & -1.159 & -0.946 & -1.020 & -0.125 & -1.685 & 0.688 & 1.317 & -0.522 & 10 \\
\hline Posti Ltd & 0.067 & -0.504 & -0.946 & 1.020 & -0.125 & -1.247 & -0.531 & 0.658 & -0.201 & 8 \\
\hline AN Post & -0.809 & 0.151 & -0.946 & -1.020 & -1.344 & 0.506 & -0.938 & -1.317 & -0.714 & 11 \\
\hline Bpost & 0.067 & 1.461 & 0.750 & 0.000 & 1.500 & 0.067 & -0.938 & 0.658 & 0.446 & 4 \\
\hline Česká pošta & -0.371 & 0.151 & 0.750 & 0.000 & -0.125 & -0.371 & -0.531 & 0.658 & 0.020 & 6 \\
\hline Deutsche Post & -0.371 & -1.159 & 0.750 & -1.020 & -0.938 & 0.506 & 0.688 & 0.658 & -0.111 & 7 \\
\hline La Poste & 0.944 & 1.461 & 1.174 & 1.020 & 2.313 & 0.944 & 2.313 & 0.658 & 1.353 & 1 \\
\hline Lietuvos Pastas & 0.944 & -0.504 & -0.946 & -1.530 & -0.938 & -0.809 & -0.938 & -1.317 & -0.755 & 12 \\
\hline Magyar Posta & -0.809 & -1.814 & -1.794 & -0.510 & 0.281 & -0.371 & -0.938 & -1.317 & -0.909 & 13 \\
\hline Poste Italiane & -0.371 & 0.151 & 0.750 & 0.000 & -0.938 & 2.259 & 0.281 & -0.658 & 0.184 & 5 \\
\hline PostNL & 0.067 & 0.151 & 1.598 & 1.020 & 0.281 & -0.371 & 1.500 & 1.317 & 0.695 & 3 \\
\hline
\end{tabular}




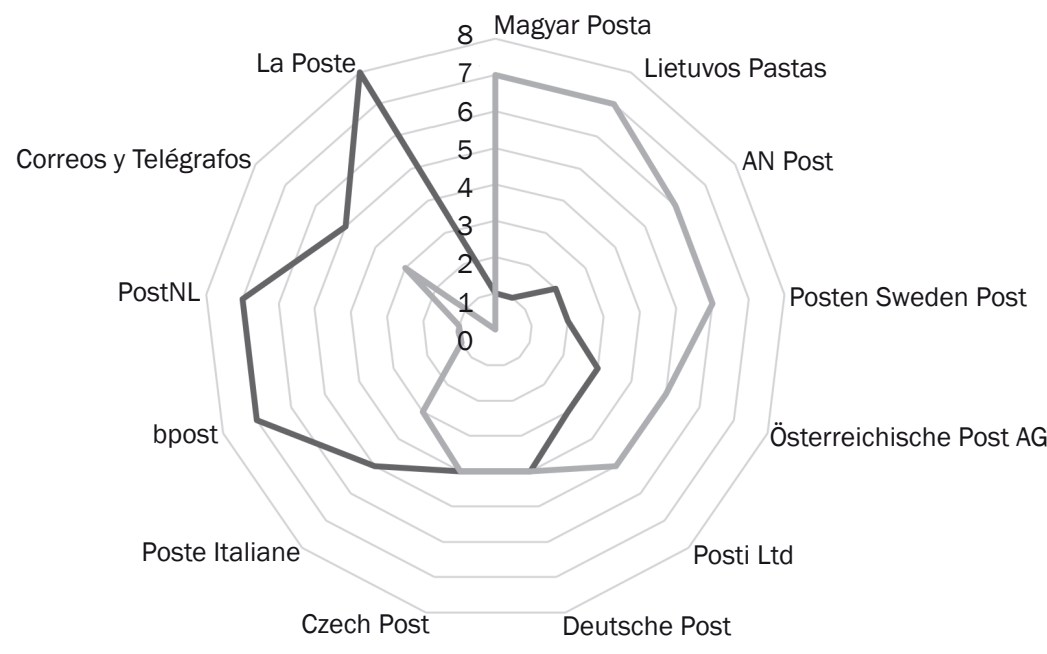

Number of positive z-scores

Number of negative z-scores

Figure 1 - Number of positive and negative z-scores

\section{DISCUSSION}

Human capital in the postal service sector is an area which has yet to be scientifically explored as it receives little attention. For this reason, the results of this study are rather unique and bring new detailed insights both into research on human capital and postal service market.

The results shown in Table 2 confirm that significant differences in approach to human capital management were found. These differences can be discussed from a number of perspectives, such as geographical, economic-administrative, and social.

As Figure 2 shows, a possible relationship can be established between the values of $\mathrm{HCl}$ and the geographical position of a country where a given NPP operates.

NPPs can be divided into four groups based on their $\mathrm{HCl}$ value: the highest scores were achieved by NPPs in Western Europe (PostNL, bpost, La Poste, Correos y Telégrafos); the second group consists of NPPs situated in Central Europe (Deutsche Post, Česká pošta, Österreichische Post AG, Poste Italiane), while the third group comprises NPPs from Northern Europe (AN Post, Posten Sweden Post, Posti Ltd). The NPPs in the second and third groups showed more or less similar scores, however, most of Central European NPPs showed better absolute values of overall $\mathrm{HCl}$ than Northern European states (see Table 2). The fourth group is formed by NPPs from Eastern Europe (Lietuvos Pastas, Magyar Posta), who achieved the lowest overall $\mathrm{HCl}$ scores. This result supports the thesis that countries situated in the east of Europe lag behind their western counterparts in many key areas (economic stability, education, level of social responsibility, etc.).
On the other hand, historical development cannot account for the differences that are found between NPPs from Western Europe and their northern counterparts. Although the development of these countries was similar in the last few decades, the differences in their overall $\mathrm{HCl}$ values are significant. It is thus clear that the sole aspect of geographical position cannot explain the differences in approach to human capital management.

The partial connections between the overall $\mathrm{HCl}$ value and the geographical position could be built on in further research that would investigate explanatory variables in their connection to these two aspects. Such research would bring new insights into regional studies, whose works usually investigate causal relationships between indicators of economic development, political stability, or indicators of society development and geographical position.

Another point of view which can shed some light on the reasons for differences in approach to human capital management is the economic-administrative perspective. This perspective addresses the differences in number of employees, internal organization (if they belong to international groups), as well as the legal perspective (NPP as a state-owned enterprise, private enterprise, private enterprise with government participation).

Regarding NPP size, a causal link between the number of employees and overall $\mathrm{HCl}$ value cannot be established. For this reason, it cannot be confirmed that NPPs with a higher number of employees score higher on the overall $\mathrm{HCl}$, meaning that they organize more activities targeting human capital. For example, Poste Italiane employed 138,236 employees, while Česká pošta employed 31,416 employees and yet managed to reach a similar overall $\mathrm{HCl}$. At the same 


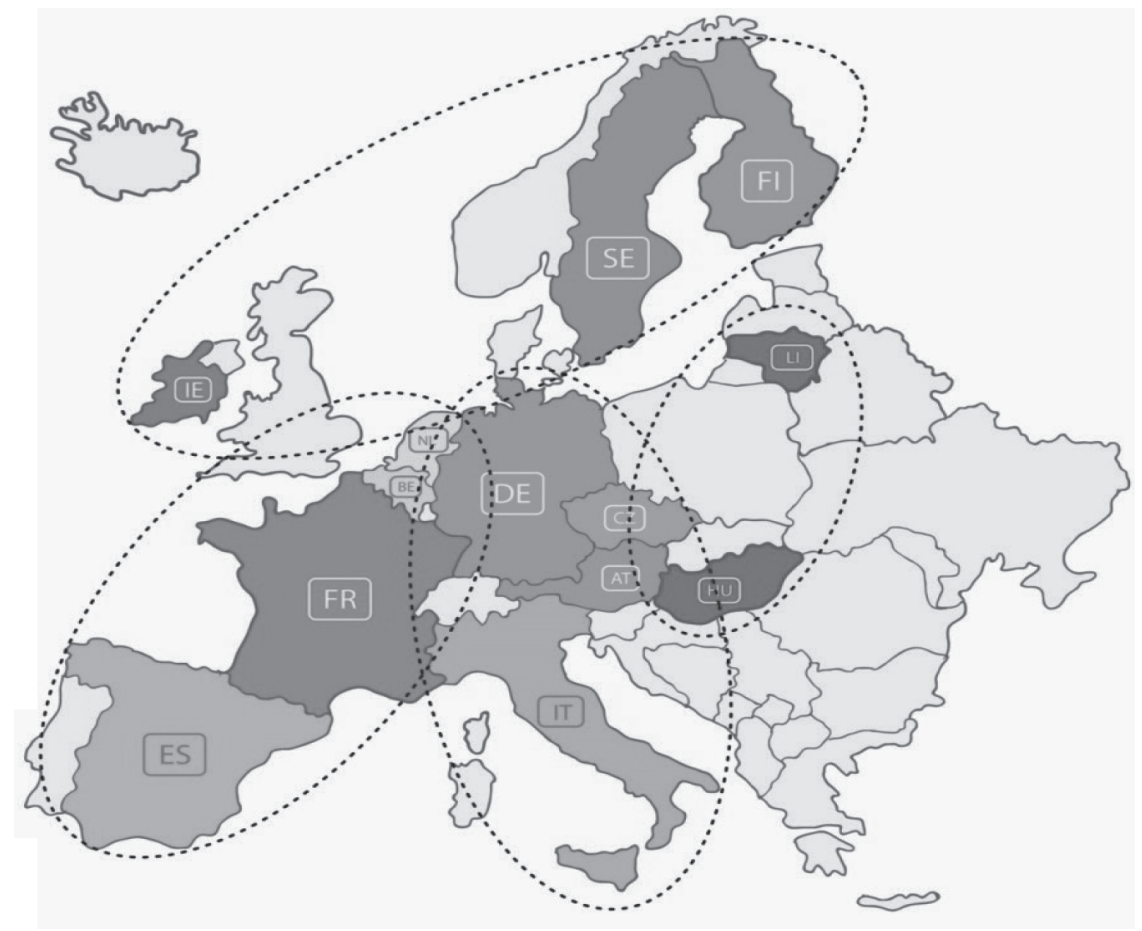

Figure 2 - Graphical expression of $\mathrm{HCl}$ in European NPPs

time, bpost employed 26,381 employees and had a higher overall $\mathrm{HCl}$ score than Poste Italiane and Česká pošta (all data as of 2015).

Regarding the inclusion of NPPs into organization structure of other subjects (international or national group of companies), numerous differences can be found in this area as well.

An interesting fact emerged in this connection: NPPs who achieved the highest score on overall $\mathrm{HCl}$ (La Poste and Correos y Telégrafos) are not independent companies but belong to a larger national group of companies. La Poste forms a part of La groupe La poste, which is structured around five business units: the Services-Mail-Parcels business unit, the GeoPost business unit, La Banque Postale, La Poste Network, and the Digital Services business unit. Spain's NPP Correos y Telégrafos also forms a part of a larger group: Correos Telecom, S.A., Nexea Gestión Documental, S.A., Correos Express Paquetería Urgente, S.A. It can therefore be assumed that NPPs that function as parts of big corporations are more likely to organize more activities connected to human capital development. Deutsche Post is also part of a larger corporation - DHL Group, but by far does not reach the score achieved by Spain or France. This can be explained by the organizational structure of the above mentioned subjects into corporations. La Poste and Correos y Telégrafos are national corporations with tight links among its units, while Deutsche Post belongs to the international corporation DHL Group, which is organized in a completely different way - entities organized into the DHL Group operate independently with no requirement for tight cooperation among its members.

Some differences can also be observed in the legal framework under which NPPs operate. NPPs such as Poste Italiane, bpost, La Poste, Deutsche Post or Post$\mathrm{NL}$ are fully or partly privatized, while Magyar Posta is owned by the Hungarian National Asset Management Inc. (HNAM). As one of the most important supporting organizations of the Ministry of National Development, HNAM exercises ownership rights over state assets worth more than 17 trillion Hungarian forints, representing almost 50 percent of Hungary's annual GDP. A similar situation prevails in the Czech Republic, where Česká pošta is state-owned, as well as Spain's Correos y Telégrafos.

Following this, no link between the type of ownership and the value of overall $\mathrm{HCl}$ can be observed.

Another perspective that is taken into account is the social perspective: it is possible to explain the differences in overall $\mathrm{HCl}$ scores using the data on a society's development level.

It has already been mentioned that countries from Eastern Europe achieved the lowest overall $\mathrm{HCl}$ scores. This suggests a small number of activities that are organized in these NPPs in order to develop human capital. This fact can perhaps be attributed to the historical development of these countries, which was rather different from the rest of Europe until the 1980s.

This group of post-communist countries also includes the Czech Republic, whose democratic development was faster thanks to its central position, close 
to other democratic states. Its geographical position thus accelerated the development of democracy after the fall of communism. This is supported by the values of its Human Development Index: between the years 1990 and 2015, the Czech Republic always reached a better score on the Human Development Index than Hungary and Lithuania [37].

NPPs whose countries have lower Human Development Index scores also achieve lower overall $\mathrm{HCl}$ scores. It should then follow that the highest $\mathrm{HCl}$ are achieved by NPPs from countries with a high Human Development Index score.

Countries such as Finland, Sweden and Ireland are in the long-term perspective countries whose Human Development Index is among the highest in the world. Surprisingly, NPPs from these countries achieve only very low overall $\mathrm{HCl}$ scores.

An explanation is offered by Ping Chu and Ghosh $[38,39]$ : in their opinion, the most developed countries (among which Finland, Sweden and Ireland can certainly be included) lack the need to formally modify aspects relating to behavior of individuals within a group, formalize rules related to discrimination against other cultures, etc. The results of this study confirm their findings. All NPPs from Northern European states (AN Post, Posten Sweden Post, Posti Ltd.) which continually rank high on the Human Development Index, achieved low scores in components $\mathrm{F}$ and $\mathrm{G}$ (components related to social climate - see Table 2) when compared to other NPPs. Posten Sweden Post and Posti Ltd show in component $F$ (Diversity management) the lowest score when compared to the rest of NPPs, which means that they do not organize any activities in this component.

\section{CONCLUSION}

Human capital is currently a highly discussed topic, especially because of its positive impact on the added value of a company. There is a number of works dealing with human capital in various areas of national economy, however, human capital in the postal service sector has received very little attention. Due to the absence of any research into this topic, the main aim of this article was to define the differences in approach to human capital management in selected NPPs. It was necessary to carry out a content analysis of annual reports in order to identify activities that reflect current approach to human capital. Identified activities were then subjected to evaluation, which provided a solid basis for definition of differences among selected NPPs. Differences are expressed via overall $\mathrm{HCl}$. This methodology was chosen because it allows for a clear distinction in approach to management of each activity in an NPP as opposed to approach of the remaining NPPs.
The results of this article show that the highest $\mathrm{HCl}$ value was yielded by the French La Poste (1.3781). This was also the only NPP that had zero negative scores, meaning that none of the activities are managed worse than the average value of this activity among the thirteen selected NPPs. The opposite is true for Lithuanian NPP, which scored the lowest (-0.797). Partial z-scores also confirm that NPPs situated in the north of Europe have generally lower results of the component $\mathrm{H}$ (Diversity management) than the remaining NPPs. This can be attributed to the level of advancement of the Northern European societies. There are also differences among NPPs in respect to relation of overall $\mathrm{HCl}$ value and the geographical position of the state. Four main groups that show similar results can be identified. These groups are geographically determined.

It can be concluded that the results of this study bring new insights into the topic of human capital and provide a solid ground for further research.

\section{ACKNOWLEDGMENT}

The article was supported by the student grant SGS_2017_009.

Ing. DALIBOR GOTTWALD, Ph.D. ${ }^{1}$

E-mail: dalibor.gottwald@upce.cz

Ing. EVA ZÁKOROVÁ, Ph.D. ${ }^{1}$

E-mail: eva.zakorova@upce.cz

doc. Ing. LIBOR ŠVADLENKA, Ph.D. ${ }^{1}$

E-mail: libor.svadlenka@upce.cz

Mgr. HANA PAVLISOVÁ ${ }^{2}$

E-mail: h.pavlisova@post.cz

1 Univerzita Pardubice,

Dopravní fakulta Jana Pernera

Studentská 95, 53210 Pardubice, Czech Republic

2 Univerzita Palackého v Olomouci, Filozofická fakulta Kř̌žkovského 10, 77200 Olomouc, Czech Republic

\section{PŘÍSTUP K LIDSKÉMU KAPITÁLU V PODMÍNKÁCH EVROPSKÝCH NÁRODNÍCH POŠTOVNÍCH OPERÁTORŮ: CROSS-COUNTRY ANALÝZA}

\section{ABSTRAKTNÍ}

Článek se zabývá problematikou lidského kapitálu v podmínkách národních poštovních operátorů (NPO), což je oblast, která stále není dostatečně vědecky probádána. $V$ současné době existuje rada prací zabývající se problematikou lidského kapitálu, avšak jen několik z nich se věnuje dané problematice $v$ oblasti poštovnich služeb. Hlavním cílem článku je identifikovat rozdíly $v$ prístupu $k$ lidskému kapitálu ve vybraných evropských NPO. Tyto rozdíly jsou vyjádřeny prostřednictvím souhrnného indexu lidského kapitálu. Vzhledem $k$ tomu, že do současné doby nebyla k dispozici žádná studie, která by se zabývala analýzou přístupu k lidskému kapitálu v oblasti evropských NPO, bylo nutné přistoupit $k$ realizaci kvantitativní obsahové analýze výročních zpráv vybraných evropských NPO. Výsledky kvantitativní obsahové analýzy výročních zpráv následně sloužily jako podklad pro vyjádření souhrnného indexu lidského kapitálu. 
Přínos článku spočivá zejména $v$ demostrování nových poznatků $v$ dané oblasti, což prispívá $k$ zajištěné udržitelného rozvoje sektoru poštovních služeb.

\section{KLÍČOVÁ SLOVA}

lidský kapitál, národní poštovní operátoři, poštovní služby;

\section{REFERENCES}

[1] Schiek D. Economic and Social Integration: The Challenge for EU Constitutional Law. Massachusetts: Edward Edgar Publishing Limited; 2012.

[2] Sarac D, Kopic M, Mostarac K, Kujacic M, Jovanovic B. Application of set covering location problem for organizing the public postal network. Promet - Traffic \& Transportation. 2016;28(4): 403-13.

[3] Coleman JS. Social Capital in the Creation of Human-Capital. American Journal of Sociology. 1988;94: S95-S120.

[4] Edvinsson L, Malone MS. Intellectual Capital: Realizing Your Company's True Value by Finding Its Hidden Brainpower. New York: Harper Business; 1997.

[5] Donate MJ, Pena I, de Pablo JDS. HRM practices for human and social capital development: Effects on innovation capabilities. International Journal of Human Resource Management. 2016;27(9): 928-53.

[6] Marzo G, Scarpino E. Exploring intellectual capital management in SMEs: An in-depth Italian case study. Journal of Intellectual Capital. 2016;17(1): 27-51.

[7] Rossi C, Cricelli L, Grimaldi M, Greco M. The strategic assessment of intellectual capital assets: An application within Terradue Srl. Journal of Business Research. 2016;69(5): 1598-603.

[8] Yaseen SG, Dajani D, Hasan Y. The impact of intellectual capital on the competitive advantage: Applied study in Jordanian telecommunication companies. Computers in Human Behavior. 2016;62: 168-75.

[9] Zéghal D, Maaloul A. Analysing value added as an indicator of intellectual capital and its consequences on company performance. Journal of Intellectual Capital. 2010;11(1): 39-60.

[10] Scafarto V, Ricci F, Scafarto F. Intellectual capital and firm performance in the global agribusiness industry: The moderating role of human capital. Journal of Intellectual Capital. 2016;17(3): 530-52.

[11] Singh B, Rao MK. Effect of intellectual capital on dynamic capabilities. Journal of Organizational Change Management. 2016;29(2): 129-49.

[12] Mehralian G, Rasekh HR, Akhavan P, Sadeh MR. The Impact of Intellectual Capital Efficiency on Market Value: An Empirical Study from Iranian Pharmaceutical Companies. Iranian Journal of Pharmaceutical Research. 2012;11(1): 195-207.

[13] Collewaert V, Manigart S. Valuation of Angel-Backed Companies: The Role of Investor Human Capital. Journal of Small Business Management. 2016;54(1): 356-72.

[14] de Albuquerque NR, Vellasco MMMR, Mun J, Housel TJ. Human Capital valuation and return of investment on corporate education. Expert Systems with Applications. 2012;39(15): 11934-43.

[15] Shahzad K, Bajwa SU, Ansted RB, Mamoon D, Rehman $\mathrm{KU}$. Evaluating human resource management capaci- ty for effective implementation of advanced metering infrastructure by electricity distribution companies in Pakistan. Utilities Policy. 2016;41: 107-17.

[16] Czaller L. Increasing social returns to human capital: Evidence from Hungarian regions. Regional Studies. 2016;51(3): 1-11.

[17] Ngcwangu S. The Ideological Underpinnings of World Bank TVET Policy: Implications of the Influence of Human Capital Theory on South African TVET Policy. Education as Change. 2015;19(3): 24-45.

[18] Weckroth M, Kemppainen T. Human capital, cultural values and economic performance in European regions. Regional Studies, Regional Science. 2016;3(1): 239-57.

[19] Kirdina SG. Methodological institutionalism as a new principle of complex social systems' analysis at meso-level. Terra Economicus. 2016;14(1): 98-108.

[20] Polachek SW, Das T, Thamma-Apiroam R. Micro- and Macroeconomic Implications of Heterogeneity in the Production of Human Capital. Journal of Political Economy. 2015;123(6): 1410-55.

[21] Wright PM, Boswell WR. Desegregating HRM: A review and synthesis of micro and macro human resource management research. Journal of Management. 2002;28(3): 247-76.

[22] Ployhart RE, Moliterno TP. Emergence of the human capital resource: A multilevel model. Academy of Management Review. 2011;36(1): 127-50.

[23] Nielsen K. Human capital and new venture performance: The industry choice and performance of academic entrepreneurs. Journal of Technology Transfer. 2015;40(3): 453-74.

[24] Ployhart RE, Nyberg AJ, Reilly G, Maltarich MA. Human Capital Is Dead; Long Live Human Capital Resources! Journal of Management. 2014;40(2): 371-98.

[25] Vieira VR. Public and private: Change and continuity in economy through two meta-fields in society. Cambridge Review of International Affairs. 2014;27(1): 21-38.

[26] Pollitt M, Stern J. Human resource constraints for electricity regulation in developing countries: Developments since 2001. Utilities Policy. 2011;19(2): 53-60.

[27] Slack R, Munz M. Intellectual capital reporting, leadership and strategic change. Journal of Applied Accounting Research. 2016;17(1): 61-83.

[28] Priyadharshini SK, Kamalanabhan TJ, Madhumathi R. Human resource management and firm performance. International Journal of Business Innovation and Research. 2015;9(2): 229-50.

[29] Sharma JK, Shukla S. Strategic HR orientation of companies in India: A content analysis approach. Prabandhan: Indian Journal of Management. 2015;8(7): 7-22.

[30] Kateb I. Voluntary human capital disclosure in French annual reports. International Journal of Learning and Intellectual Capital. 2015;12(4): 323-41.

[31] Adelowotan MO. Human capital development (HCD) through open, distance and e-learning: Evidence from corporate annual reports (Cars) of top South African listed companies. Turkish Online Journal of Distance Education. 2014;15(3): 68-79.

[32] Gamerschlag R. Value relevance of human capital information. Journal of Intellectual Capital. 2013;14(2): 325-45. 
[33] Moloi T. Governance of risks in South Africa's public higher education institutions (HEls). Investment Management and Financial Innovations. 2016;13(2): 226-34.

[34] Biswas PK, Bala SK. Usefulness of corporate annual reports to individual investors in Bangladesh. In ternational Journal of Disclosure and Governance. 2016;13(2): 97-116.

[35] D'Amico E, Coluccia D, Fontana S, Solimene S. Factors Influencing Corporate Environmental Disclosure. Business Strategy and the Environment. 2016;25(3):
178-92.

[36] Matloff N. From Algorithms to z-scores: Probabilistic and Statistical Modeling in Computer Science. Orange Grove Texts Plus; 2009.

[37] United Nations. Trends in the Human Development Index, 1990-2015 2016. Available from: http://hdr. undp.org/en/composite/trends

[38] Ping Chu JK. The Simple Science of Being. USA: Xlibris; 2004.

[39] Ghosh BN, Guven HM, editors. Globalization in Third World. New York: Palgrave Macmillan; 2006. 